\title{
Silicon particles as trojan horses for potential cancer therapy
}

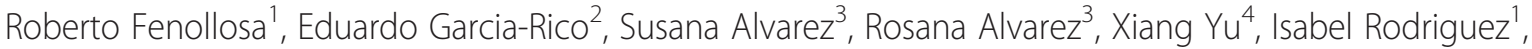 \\ Susana Carregal-Romero ${ }^{4}$, Carlos Villanueva ${ }^{5}$, Manuel Garcia-Algar ${ }^{6}$, Pilar Rivera-Gil ${ }^{5}$, Angel R de Lera ${ }^{3}$, \\ Wolfgang J Parak ${ }^{4^{*}}$, Francisco Meseguer ${ }^{1 *}$ and Ramón A Alvarez-Puebla ${ }^{6,7^{*}}$
}

\begin{abstract}
Background: Porous silicon particles (PSiPs) have been used extensively as drug delivery systems, loaded with chemical species for disease treatment. It is well known from silicon producers that silicon is characterized by a low reduction potential, which in the case of PSiPs promotes explosive oxidation reactions with energy yields exceeding that of trinitrotoluene (TNT). The functionalization of the silica layer with sugars prevents its solubilization, while further functionalization with an appropriate antibody enables increased bioaccumulation inside selected cells.

Results: We present here an immunotherapy approach for potential cancer treatment. Our platform comprises the use of engineered silicon particles conjugated with a selective antibody. The conceptual advantage of our system is that after reaction, the particles are degraded into soluble and excretable biocomponents.

Conclusions: In our study, we demonstrate in particular, specific targeting and destruction of cancer cells in vitro. The fact that the LD 50 value of PSiPs-HER-2 for tumor cells was 15-fold lower than the LD 50 value for control cells demonstrates very high in vitro specificity. This is the first important step on a long road towards the design and development of novel chemotherapeutic agents against cancer in general, and breast cancer in particular.
\end{abstract}

\section{Background}

Cancer is the second cause of death worldwide. In the case of breast cancer, epidemiological studies point to more than one million new cases diagnosed per year and an annual mortality rate close to 450,000 deaths. Particles have shown great potential [1] for drug delivery [2-4] and cancer treatment [5-8]. In most approaches, particles are directed to target cells by antibodies attached to their surfaces, which in the case of in vivo administration, supplements passive targeting through the EPR (enhanced permeability and retention) effect [9]. Some strategies involve heating particles with an external oscillating magnetic or electromagnetic field and

\footnotetext{
*Correspondence: wolfgang.parak@physik.uni-marburg.de; fmese@fis.upv.es; ramon.alvarez@urv.cat

${ }^{4}$ Fachbereich Physik, Philipps Universität Marburg, Marburg 35037, Germany ${ }^{1}$ Centro de Tecnologías Físicas, Unidad Asociada ICMM/CSIC-UPV,

Universidad Politécnica de Valencia, Av. Los Naranjos s/n, Valencia, 46022 Spain and Instituto de Ciencia de Materiales de Madrid, CSIC, Madrid 28049 Spain

${ }^{6}$ Departamento de Química Física e Inorgánica, Universitat Rovira i Virgili and Centro de Tecnología Química de Catalunya, Carrer de Marcel•lí Domingo s/n, 43007 Tarragona, Spain

Full list of author information is available at the end of the article
}

causing apoptosis of the nearby cells through magnetothermia $[10,11]$ or photothermia $[6,12-15]$. These materials suffer certain limitations, such as the large and expensive facilities (i.e. magnetic resonance imaging, MRI) necessary for magnetothermia, and the limited penetration depth of light in the body in the case of photothermia. Other approaches make use of antibody functionalized particles loaded with cancer drugs to deliver the drug to tumor cells [5,16-19]. Porous silicon particles (PSiPs) have been considered a very promising platform for cancer therapy because of their excellent biocompatibility [20] and biodegradability [5,21-23]. In all studies reported to date, PSiPs work either as a passive carrier of an anticancer cargo [5,16-19] or as an element activated by an appropriate trigger, namely light and acoustic waves for particle thermalization $[14,24,25]$ or singlet oxygen generation in photodynamic therapies [8]. Here, we demonstrate that PSiPs themselves can be used as a drug for cancer treatment and how to modulate their activity by taking advantage of their surface functionalization and the enzymatic machinery of eukaryotic cells. 
Silicon is characterized by a reduction potential [26] of $-1.697 \mathrm{eV}$ to yield silicates or $-0.91 \mathrm{eV}$ to yield silica, which is ultimately dissolved as silicates in the presence of water. The low reduction potential makes the reactions violent and even explosive [27] in nanoscaled porous particles [28]. On the other hand, the high tendency of silicon to undergo oxidation is modulated by the spontaneous generation of a passivation layer of $\mathrm{SiOx}$ when exposed to open atmosphere. Notably, this passivation layer dissolves in water and particularly in slightly acidic media. The kinetics of the dissolution of this layer can be modulated by surface functionalization of the silica. Thus, by coating with a compact monolayer of an organic molecule, dissolution can be retarded or even prevented.

The processes for obtaining PSiPs have been well known for 20 years [29]. They are mainly based on wet chemistry methods, where the starting material, bulk silicon, is converted into porous silicon, by an electrochemical or stain-etching reaction, followed by a process such as ultrasonication, to break the porous layer into small particles [30,31]. Other, less studied methods, use a bottom-up approach based on chemical vapor deposition techniques, where the starting material is a precursor gas, namely silane or di-silane, which can be decomposed at high temperatures [26]. Under controlled conditions of pressure, temperature and time, such gases nucleate and nanometric porous silicon particles can be obtained [32]. This is a complex process, and the involved mechanisms are still under study (see Methods) [33,34]. In some manner PSiPs can be regarded as a macromolecule resulting from the polymerization of disilane with a dramatic capability of oxidation.

Herein we demonstrate that silicon particles coated with a native silica layer can be engineered with the bioorganic appropriate ligands to target and accumulate into tumour cells. Once inside the cell, the particles are driven to the lysosome were the enzymatic machinery of the cell metabolize the ligands. Then, the exposition of the soluble silica coating to the aqueous lysosomal solution degrades this layer allowing water to react violently with the silicon. As result the target cells dye while the particles are degraded into soluble and excretable biocomponents.

\section{Results and discussion}

Our process to obtain the particles used in this work stem from these methods [35]. The nanostructured particles were highly spherical with a diameter between 1.5 and $2 \mu \mathrm{m}$, with an intrinsic photoluminescence in between the dark red and the near infrared (Figure 1A and B) [36]. As prepared, and after extracting the materials from the reactor, exposure to atmospheric oxygen generated a thin layer of silicon oxide (Figure $2 \mathrm{C}$ and $\mathrm{D}$ ). This coating acted as a protective shell and generated an easily functionalizable surface to couple an organic layer would protect the silica from dissolution in physiological media. The enzymatic machinery present in the cell can easily degrade this protective organic shell, which would consequently trigger oxidation reactions of the particles after their internalization by cells. To prove this concept, we used a glucopyranoside derivative that can be easily metabolized by the lysosomal enzyme $\alpha$ - $D$-glucoside glucohydrolase. The lysosome has been shown to be a target organelle for most nano- and microparticles $[37,38]$ and thus it can be predicted that after internalization by cells, the particles would be exposed to $\alpha$-D-glucoside glucohydrolase.

The sugar and the particle cannot be directly linked without previous modifications. Thus, PSiPs were capped with aminopropylsilane (APS) [39], while the glucopyranoside selected was 2 -acetamido-2-deoxy- $\beta$-D-glucopyranosyloxyacetic acid (Figure 2, see Methods and SI for details). The benzotriazol-1-yloxytris(dimethylamino)phosphonium hexafluorophosphate/anhydrous 1-hydroxybenzotriazole (BOP/ HOBt) coupling method was chosen to generate a peptide bond between the amine-functionalized particle surface and the carboxylic acid group attached to the carbohydrate. Notably, within this configuration, hybrid particles will resist oxidation in physiological media but should be degraded unselectively within any cell, following endocytosis and subsequent localization within the lysosome. Therefore, for anticancer therapy, a selective antibody that targets the surface receptor of the desired cell is necessary.

Consequently, the third step in the preparation of our immunotherapeutic material involved the coupling of a directing vector. HER-2-positive breast cancer is characterized by the amplification of this gene and high expression and activity of its protein [40]. In fact, there is a strong association between HER-2 (ErbB2) tyrosine kinase expression and the aggressiveness and prognosis of the disease. Fortunately, HER-2 amplification confers a selective target for specific treatment and several drugs targeting his receptor are actually used for breast cancer treatment in medical practice, including small molecule tyrosine kinase inhibitors (TKIs) such as gefitinib, erlotinib or lapatinib or monoclonal antibodies such as trastuzumab, pertuzumab or cetuximab [41]. HER-2 is also a standard receptor for specific targeting [42]. For our materials, rather than using standard carbodiimide chemistry, the HER-2 antibody was linked to the particles by taking advantage of its affinity for the sugar. Thus, one of the four glycosylation immunogenic regions was spontaneously coupled to the sugars present on the particle surface, allowing the other three to interact with the cell membrane receptors [43].

First, to test the interaction of our particles with the cells, the PSiP-HER-2 were internalized by the HER-2 positive cell line, SK-BR-3. The particles could be 

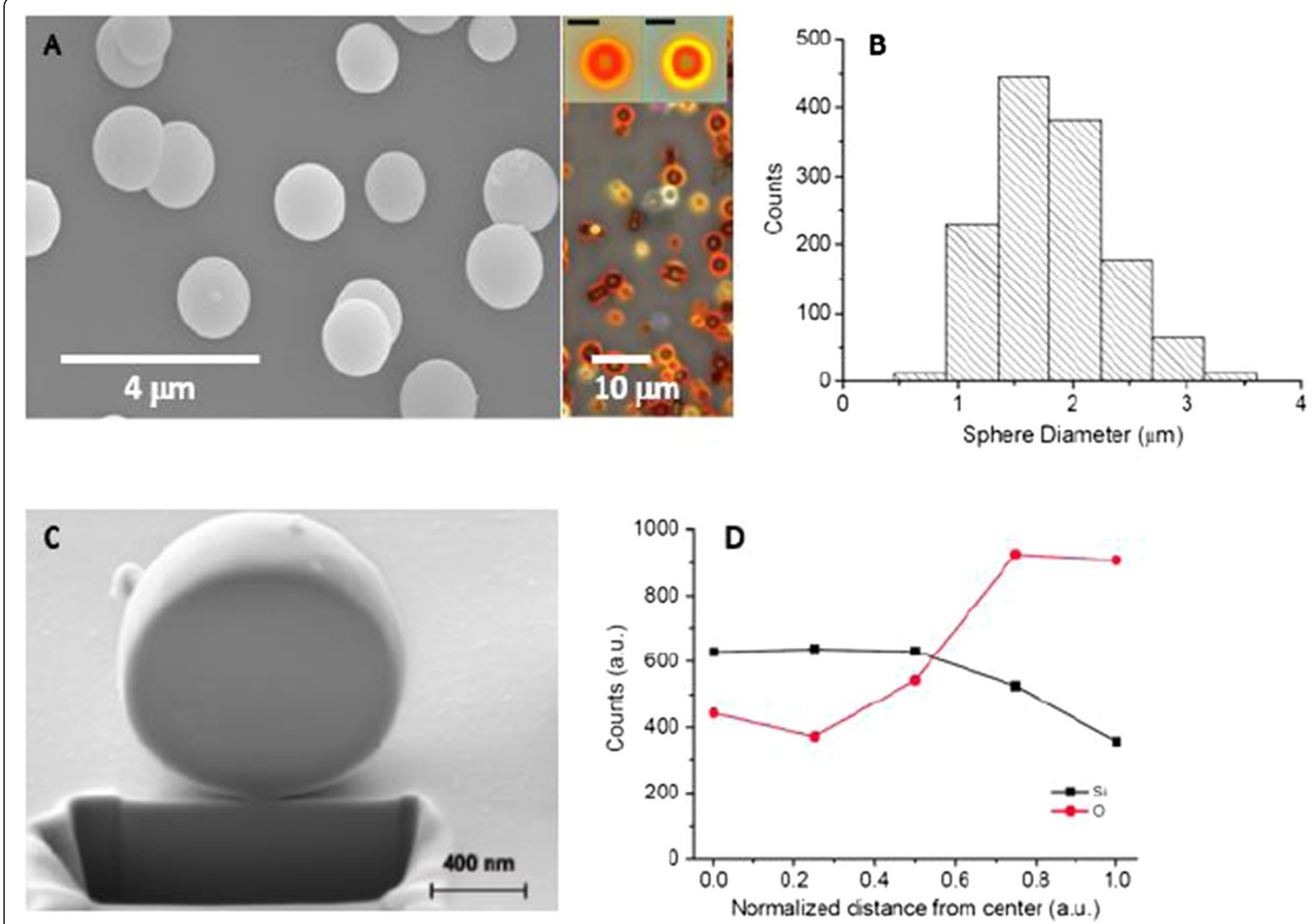

Figure 1 Silicon particle characterization. (A) SEM and optical microscopy images of the porous silicon particles as prepared and (B) their size distribution. All scale bars in the insets correspond to $2 \mu \mathrm{m}$. (C) SEM image of a porous silicon colloid carved using the focused ion beam (FIB) technique. (D) EDX analysis of materials inside a silicon colloid as a function of the distance from the sphere center, normalized to the sphere radius ( $d$ = distance from the sphere center/sphere radius). The graph shows the counts for the $\mathrm{Si}$ and $\mathrm{O}$ peaks of the EDX spectra at five different points of analysis. The points were selected along a line travelling from the nucleus $(d=0)$ to the sphere surface $(d=1)$.

visualized, surrounded by the cell membrane (Figure 3A). Some particles remained in the extracellular space, while other particles were seen attached to the cell membrane. Despite their micro-size and the degree of agglomeration, the particles could be internalized by SK-BR-3 cells without affecting their viability at an early stage. This is in agreement with other work [37] showing that particles at the micro-scale can be safely incorporated by eukaryotic cells.

Next, we tested the efficiency of the PSiPs functionalized with antibodies against HER-2 receptors (PSiPsHER-2) for their potential to selectively kill only cells overexpressing HER-2. To this end, we used two different cell lines, one overexpressing the HER-2 receptor (SK-BR-3) and one with its normal expression level (MDA-MB-435) [44]. The cells were seeded in 96-well plates and incubated with different quantities of PSiPsHER-2 for $48 \mathrm{~h}$, before a resazurin-based viability assay was performed. Resazurin is a nonfluorescent molecule that is reduced by metabolic active cells to the fluorescent resorufin. Thus, the number of viable cells can be determined by measuring resorufin fluorescence. Notably, when SK-BR-3 cells (cells overexpressing the HER-2 receptors) were treated with PSiPs-HER-2, their viability was clearly compromised (Figure 4, black points). On the other hand SK-BR-3 cells treated with PSiPs (Figure 4, blue points) or MDA-MB-435 cells treated with PSiPs or PSiPs-HER-2 (Figure 4, red and green points, respectively) showed a more delayed toxicological response. The $\mathrm{LD}_{50}$ (lethal dose killing $50 \%$ of the cell population) values are presented in Table 1 . Only around $250 \mu \mathrm{g} / \mathrm{mL}$ PSiPs-HER-2 were needed to kill $50 \%$ of the SK-BR-3 cells, whereas much higher quantities of the same particles were required under the same conditions to kill the same proportion of MDA-MB-435 cells. On the other hand, PSiPs without attached HER-2 antibodies showed a much lower toxicological response, as their $\mathrm{LD}_{50}$ values were very high for both cell types.

These results confirm the efficacy of PSiPs-HER-2 to recognize the HER-2 receptors present on the surface of 

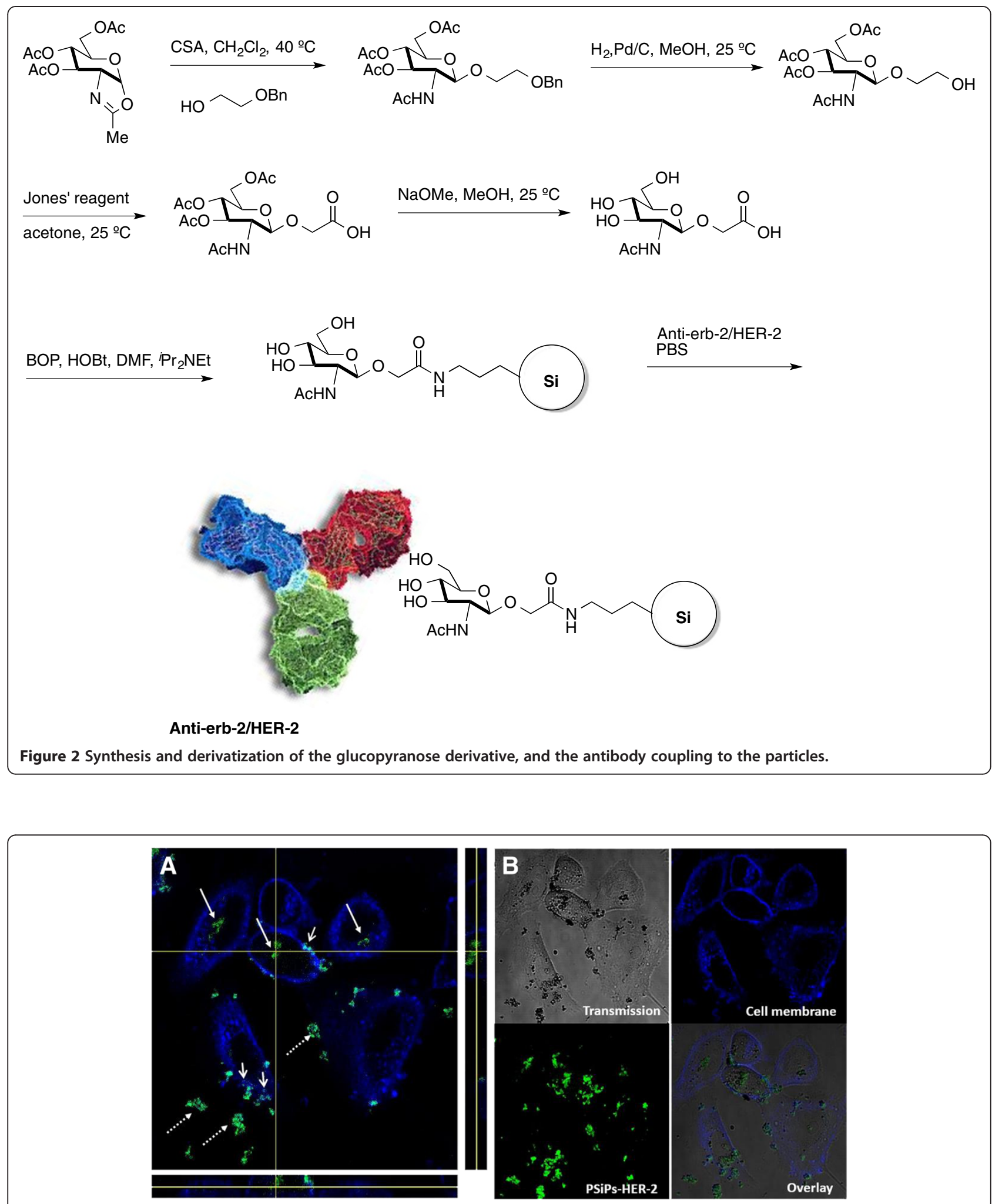

Figure 3 Particle localization into SK-BR-3 cell lines. SK-BR-3 (cell membrane labeled in blue) treated with PSiP-HER-2 particles (presented in green) for $24 \mathrm{~h}$, showing the particles inside (arrow) and, outside (dashed arrow) the cells and at the cell membrane (opened arrow). (A) Orthogonal view in the 3 planes $(X / Y, X / Z$ and $Y / Z)$ of the particles pointed at the intersection of the $X$ and $Y$ axeis. As seen from all planes, the particles are surrounded by the cell membrane. (B) Confocal images of the cells in the transmission channel, the cell membrane and PSiP-HER-2 in fluorescent channels, and overlay of all channels. PSiP-HER-2 were labeled with DyLight 488. 


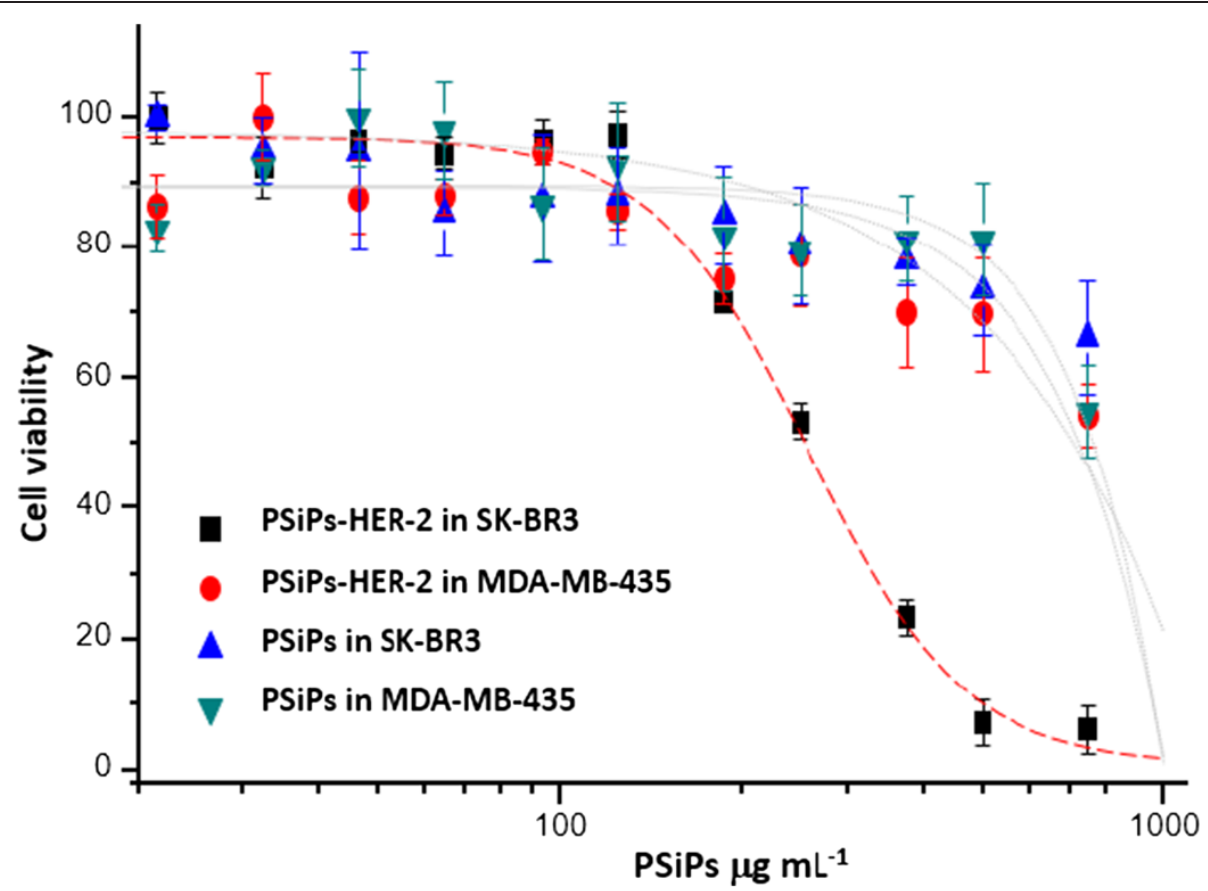

Figure 4 Cell viability. Relative cell viability after incubation of SK-BR-3 and MDA-MB-435 cells with PSiPs and PSiPs-HER-2 for $48 \mathrm{~h}$.

SK-BR-3 cells to a higher extent than that on MDA-MB435 cells and to effectively promote their local accumulation. The degree of targeting was more than sufficient to accelerate the death of the targeted cancer cells.

\section{Conclusions}

In summary, we present here an immunotherapy approach for potential cancer treatment. Our platform comprises the use of engineered silicon particles conjugated with a selective antibody. The conceptual advantage of our system is that after reaction, the particles are degraded into soluble and excretable biocomponents. In our study, we demonstrate in particular, specific targeting and destruction of cancer cells in vitro. The fact that the $\mathrm{LD}_{50}$ value of PSiPs-HER-2 for tumor cells was 15fold lower than the $\mathrm{LD}_{50}$ value for control cells demonstrates very high in vitro specificity. This is the first important step on a long road towards the design and

Table 1 Calculated LD50 obtained from the dose-response curves shown in Figure 4

\begin{tabular}{llll}
\hline Cell line & Type of NP & LD $_{\mathbf{5 0}}(\boldsymbol{\mu g} / \mathbf{m L})$ & $\mathbf{L D}_{\mathbf{5 0}} \mathbf{S D}$ \\
\hline SK-BR-3 & PSiPs-HER-2 & 249 & 10 \\
MDA-MB-435 & PSiPs-HER-2 & 3776 & 180 \\
SK-BR-3 & PSiPs & 5603 & 360 \\
MDA-MB-435 & PSiPs & 2672 & 214 \\
\hline
\end{tabular}

development of novel chemotherapeutic agents against cancer in general, and breast cancer in particular.

\section{Methods}

Synthesis of porous silicon microspheres

Our method for producing porous silicon microspheres is based on the decomposition of disilane gas $\left(\mathrm{Si}_{2} \mathrm{H}_{6}\right)$ by chemical vapor deposition (CVD). This is similar to the synthesis of silicon colloids [45], where the gas is introduced in a reactor whose walls are heated at high temperatures for a certain time, usually higher than $400^{\circ} \mathrm{C}$. During this procedure, $\mathrm{Si}_{\mathrm{n}} \mathrm{H}_{\mathrm{m}}$ clusters grow in the gas phase [46] and these become highly spherical, micrometer-sized particles, through surface tension forces. At the same time, the process of hydrogen desorption from the clusters progressively reduces the hydrogen content until they become hydrogenated amorphous silicon (a:Si-H) colloids. To obtain porous silicon microspheres, the heating process is stopped at an early stage, before the formation of amorphous silicon colloids is complete. In this way, porous particles with an undetermined composition of silicon and hydrogen atoms are obtained.

Porous silicon particles for this work were synthesized using a di-silane decomposition temperature of $400^{\circ} \mathrm{C}$. The absolute gas pressure in the reactor was about 0.25 atm at room temperature and we used decomposition times from 1 to 2 minutes, measured from the stage where the gas reaches the target temperature. 
Silicon and oxygen content of porous silicon colloids were analyzed by electron dispersive X-ray (EDX) measurements. For this purpose, colloids were carved using a focus ion beam (FIB) technique (FEI Helios NanoLab Omniprobe). Figure $1 \mathrm{C}$ shows a scanning electron microscope (SEM) image of a carved colloid, $1.2 \mu \mathrm{m}$ in diameter. The carved surface appears to be flat because the ion gun of the FIB removes material and deposits it at the same time on the surface of the particle, thus hiding porous structures. Nevertheless, because the EDX interaction volume penetrates the region where pores are less modified by the FIB carving action, one can extract useful information about the cavity structure. Figure 1D shows the EDX analysis corresponding to silicon and oxygen in different regions of the particle, from the cavity center to the cavity surface. This shows two key results: a) the oxygen content appears to be completely within the cavity and b) the oxygen (silicon) concentration increases (decreases) from the center to the surface. This result supports the hypothesis that porous silicon colloids possess a gradient, or onion-like, porous structure, as images taken by optical microscopy suggest. In addition, it indicates that porosity is higher at the surface of the colloid than within it.

\section{Synthesis of the 2-acetamido-2-deoxy- $\beta$-d-glucopyranosy- loxyacetic acid}

Solvents were dried according to published methods and distilled before use. All other reagents were commercial compounds of the highest purity available. Unless otherwise indicated, all reactions involving air- and moisture-sensitive materials were carried out under an argon atmosphere, while those not involving aqueous reagents were carried out in oven-dried glassware. Analytical thin layer chromatography (TLC) was performed on aluminum plates with Merck Kieselgel 60 F254 and visualized by UV irradiation (254 $\mathrm{nm}$ ) or by staining with an ethanolic solution of phosphomolybdic acid. Flash column chromatography was carried out using Merck Kieselgel 60 (230-400 mesh) under pressure. ${ }^{1} \mathrm{H}$ NMR spectra were recorded in $\mathrm{CDCl}_{3}$ and $\mathrm{D}_{2} \mathrm{O}$, at ambient temperature on an AMX-400 spectrometer at $400 \mathrm{MHz}$, with residual protic solvent as the internal reference $\left[\mathrm{CDCl}_{3}, \delta_{\mathrm{H}}=7.26 \mathrm{ppm}\right]$; chemical shifts $(\delta)$ are given in parts per million, and coupling constants $(J)$ are given in Hertz. The proton spectra are reported as follows: $\delta$ (multiplicity, coupling constant $J$, number of protons, assignment).

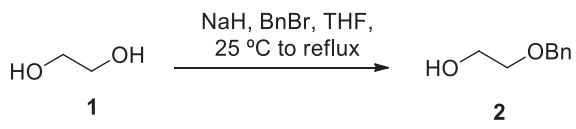

2-(Benzyloxy)ethanol 2. To a mixture of $\mathrm{NaH}$ (3.4 g, $0.085 \mathrm{~mol}, 60 \% \mathrm{w} / \mathrm{w}$ in mineral oil) in tetrahydrofuran
(THF, $150 \mathrm{~mL}$ ), ethylene glycol 1 (25.1 mL, $0.45 \mathrm{~mol})$ was added and the mixture was stirred for $1 \mathrm{~h}$ at $25^{\circ} \mathrm{C}$. Then, benzyl bromide $(8.9 \mathrm{~g}, 0.075 \mathrm{~mol})$ was added and the reaction was refluxed for $12 \mathrm{~h}$. After cooling the mixture $\left(0^{\circ} \mathrm{C}\right)$, a saturated aqueous solution of $\mathrm{NH}_{4} \mathrm{Cl}$ was added, the solvent was evaporated and the mixture was extracted with EtOAc $(3 \times)$. The combined organic layers were washed with a saturated aqueous solution of $\mathrm{NH}_{4} \mathrm{Cl}$ and brine, and dried $\left(\mathrm{Na}_{2} \mathrm{SO}_{4}\right)$. The solvent was evaporated to afford $11.22 \mathrm{~g}$ (98\% yield) of a colorless oil identified as 2-(benzyloxy)ethanol 2. The spectroscopic data were identical to those described in the literature [47]. ${ }^{1} \mathrm{H}-\mathrm{NMR}\left(400 \mathrm{MHz}, \mathrm{CDCl}_{3}\right): \delta$ 7.40-7.30 (m, 5H), $4.58(\mathrm{~s}, 2 \mathrm{H}), 3.78(\mathrm{t}, J=5.0 \mathrm{~Hz}, 2 \mathrm{H}), 3.61(\mathrm{t}, J=4.9 \mathrm{~Hz}$, 2H), 2.06 (br, 1H, OH) ppm.

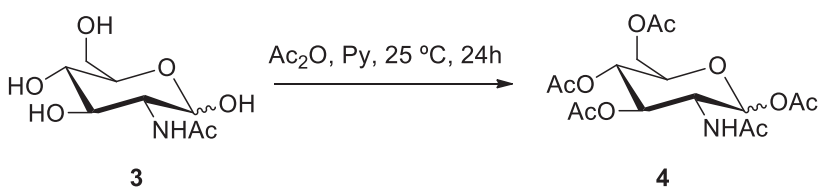

1,3,4,6-tetra- $O$-acetyl- $\alpha / \beta$ - $N$-acetylglucosamine 4 . $N$-acetylD-glucosamine 3 (5 g, $22.6 \mathrm{mmol}$ ) was dissolved in pyridine $(36 \mathrm{~mL})$ and acetic anhydride $(25 \mathrm{~mL})$ was added dropwise at $0^{\circ} \mathrm{C}$. The reaction mixture was stirred at $25^{\circ} \mathrm{C}$ for $24 \mathrm{~h}$, then diluted with $\mathrm{CH}_{2} \mathrm{Cl}_{2}$ and washed consecutively with cold water, a saturated aqueous solution of $\mathrm{NaHCO}_{3}$, and a $10 \%$ aqueous solution of $\mathrm{CuSO}_{4}$. The organic layer was dried $\left(\mathrm{Na}_{2} \mathrm{SO}_{4}\right)$ and the solvent was evaporated to obtain $6.60 \mathrm{~g}(75 \%)$ of a white solid identified as $1,3,4,6$-tetra- $O$-acetyl- $\alpha / \beta-N$-acetylglucosamine 4 . The spectroscopic data were identical to those described in the literature [48]. ${ }^{1} \mathrm{H}-\mathrm{NMR}\left(400 \mathrm{MHz}, \mathrm{CDCl}_{3}\right): \delta 6.17$ (d, $J=3.6 \mathrm{~Hz}, 1 \mathrm{H}), 5.64(\mathrm{~d}, J=9.3 \mathrm{~Hz}, 1 \mathrm{H}), 5.30-5.20(\mathrm{~m}, 2 \mathrm{H})$, 4.49 (ddd, $J=10.6,8.9,3.6 \mathrm{~Hz}, 1 \mathrm{H}), 4.25$ (dd, $J=12.5$, $4.1 \mathrm{~Hz}, 1 \mathrm{H}), 4.07$ (dd, $J=12.5,2.4 \mathrm{~Hz}, 1 \mathrm{H}), 4.00$ (ddd, $J=9.6,4.0,2.3 \mathrm{~Hz}, 1 \mathrm{H}), 2.20$ (s, 3H), 2.09 (s, 3H), 2.06 (s, 3H), 2.05 (s, 3H), $1.94(\mathrm{~s}, 3 \mathrm{H}) \mathrm{ppm}$.

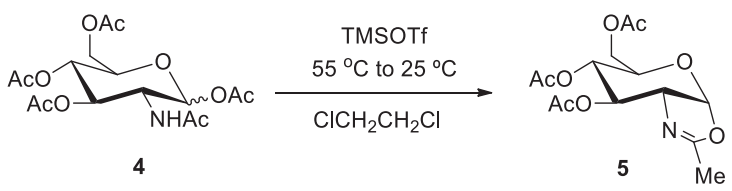

$4^{\prime}, 5^{\prime}$-Dihydro-2' -methyloxazolo $\left[5^{\prime}, 4^{\prime}: 1,2\right]-3,4,6$-tri- $O$ acetyl-1,2-dideoxy- $\alpha$-D-glucopyranoside 5 . To a solution of 1,3,4,6-tetra- $O$-acetyl- $\alpha / \beta-N$-acetylglucosamine 4 (2.49 g, $6.4 \mathrm{mmol})$ in dichloroethane $(25 \mathrm{~mL})$ TMSOTf $(1.8 \mathrm{~mL}$, $9.6 \mathrm{mmol}$ ) was added and the reaction was stirred for $2 \mathrm{~h}$ at $55^{\circ} \mathrm{C}$ and for $12 \mathrm{~h}$ at $25^{\circ} \mathrm{C}$. A saturated aqueous solution of $\mathrm{NaHCO}_{3}$ was added and the mixture was extracted with 
$\mathrm{CH}_{2} \mathrm{Cl}_{2}(3 \times)$. The combined organic layers were washed with a saturated aqueous solution of $\mathrm{NaHCO}_{3}$ and dried $\left(\mathrm{Na}_{2} \mathrm{SO}_{4}\right)$ and the solvent was evaporated. The resulting residue was purified by column chromatography (silica gel, 97:3 $\left.\mathrm{CH}_{2} \mathrm{Cl}_{2} / \mathrm{MeOH}\right)$ to afford $1.86 \mathrm{~g}(78 \%)$ of $4^{\prime}, 5^{\prime}$-dihydro$2^{\prime}$-methyloxazolo $\left[5^{\prime}, 44^{\prime}: 1,2\right]-3,4,6$-tri-O-acetyl-1,2-dideoxy- $\alpha$ $\mathrm{D}$-glucopyranoside 5 . The spectroscopic data were identical to those described in the literature [49]. ${ }^{1} \mathrm{H}-\mathrm{NMR}(400 \mathrm{MHz}$, $\left.\mathrm{CDCl}_{3}\right): \delta 5.98(\mathrm{~d}, J=7.4 \mathrm{~Hz}, 1 \mathrm{H}), 5.27(\mathrm{t}, J=2.4 \mathrm{~Hz}, 1 \mathrm{H})$, 4.94 (ddd, J = 9.2, 2.0, $1.2 \mathrm{~Hz}, 1 \mathrm{H}), 4.19-4.14(\mathrm{~m}, 3 \mathrm{H}), 3.62$ (dt, J=8.8, 4.3 Hz, 1H), $2.12 \mathrm{~Hz}(\mathrm{~s}, 3 \mathrm{H}), 2.11$ (s, 3H), 2.10 (s, 3H), 2.09 (s, 3H) ppm.

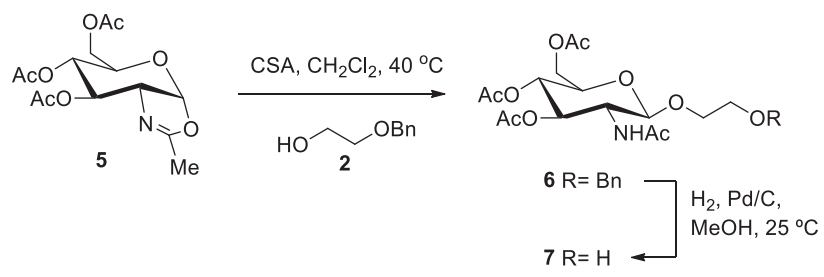

2-Hydroxyethyl-2-acetamido-3,4,6-tri-O-acetyl-2-deox y- $\beta$-D-glucopyranoside 7. 10-( $R$-camphorsulfonic acid (1.40 g, $5.02 \mathrm{mmol}$ ) and 2-(benzyloxy)ethanol 2 (7.63 g, $50.2 \mathrm{mmol})$ were added to a stirred solution of $4^{\prime}, 5^{\prime}$ dihydro-2' -methyloxazolo $\left[5^{\prime}, 4{ }^{\prime}: 1,2\right]-3,4,6$-tri- $O$-acetyl1,2-dideoxy- $\alpha$-D-glucopyranoside 5 (1.86 g, $5.02 \mathrm{mmol}$ ) and powdered $4 \AA$ molecular sieves (ca. $8 \mathrm{~g}$ ) in $\mathrm{CH}_{2} \mathrm{Cl}_{2}$ $(30 \mathrm{~mL})$ and the reaction was stirred at $40^{\circ} \mathrm{C}$ for $14 \mathrm{~h}$. The mixture was cooled to $0^{\circ} \mathrm{C}$ and a saturated aqueous solution of $\mathrm{NaHCO}_{3}(60 \mathrm{~mL})$ and $\mathrm{CH}_{2} \mathrm{Cl}_{2}(30 \mathrm{~mL})$ was added. The layers were separated and the organic layer was washed with a saturated aqueous solution of $\mathrm{NaHCO}_{3}$, brine and dried $\left(\mathrm{Na}_{2} \mathrm{SO}_{4}\right)$, and the solvent then evaporated. The residue was purified by column chromatography (hexane/EtOAc 50:50 to $\mathrm{CH}_{2} \mathrm{Cl}_{2} / \mathrm{MeOH}$ 95:5) providing 2-O-benzyloxyethyl-2-acetamido-3,4,6-tri-O-acetyl2 -deoxy- $\beta$-D-glucopyranoside 6 as a colorless solid. The spectroscopic data of the product were identical to those described in the literature [50]. ${ }^{1} \mathrm{H}-\mathrm{NMR}(400 \mathrm{MHz}$, $\left.\mathrm{CDCl}_{3}\right): \delta 7.4-7.3(\mathrm{~m}, 5 \mathrm{H}), 5.50(\mathrm{~d}, J=8.8 \mathrm{~Hz}, 1 \mathrm{H}), 5.25(\mathrm{dd}$, $J=10.4,9.4 \mathrm{~Hz}, 1 \mathrm{H}), 5.09(\mathrm{t}, J=9.6 \mathrm{~Hz}, 1 \mathrm{H}), 4.76(\mathrm{~d}$, $J=8.4 \mathrm{~Hz}, 1 \mathrm{H}), 4.56(\operatorname{app~s}, 2 \mathrm{H}), 4.27(\mathrm{dd}, J=12.3,4.7 \mathrm{~Hz}$, $1 \mathrm{H})$, 4.20-4.15 (m, 2H), 3.99 (dt, $J=11.5,3.9 \mathrm{~Hz}, 1 \mathrm{H}), 3.80$ (ddd, $J=18.2,14.7,11.2 \mathrm{~Hz}, 1 \mathrm{H}), 3.70-3.65$ (m, 3H), 2.09 (s, $3 \mathrm{H}), 2.06$ (s, 3H), 2.03 (s, 3H), 1.87 (s, 3H) ppm.

A mixture of 2-O-benzyloxyethyl-2-acetamido-3,4,6-tri-Oacetyl-2-deoxy- $\beta$-D-glucopyranoside 6 (0.19 g, $0.36 \mathrm{mmol})$ and $\mathrm{Pd} / \mathrm{C}(10 \%, 0.02 \mathrm{~g})$ in $\mathrm{MeOH}(3 \mathrm{~mL})$ was stirred under an $\mathrm{H}_{2}$ atmosphere for $7 \mathrm{~h}$ at $25^{\circ} \mathrm{C}$. The reaction was filtered through Celite and the solvent was evaporated to afford $0.15 \mathrm{~g}$ (96\%) of a solid identified as 2-hydroxyethyl2 -acetamido-3,4,6-tri-O-acetyl-2-deoxy- $\beta$-D-glucopyranoside
7. The spectroscopic data of the product were identical to those described in the literature [50]. ${ }^{1} \mathrm{H}-\mathrm{NMR}(400 \mathrm{MHz}$, $\left.\mathrm{CDCl}_{3}\right): \delta 5.58(\mathrm{~d}, J=9.0 \mathrm{~Hz}, 1 \mathrm{H}), 5.25(\mathrm{dd}, J=10.6,9.4 \mathrm{~Hz}$, $1 \mathrm{H}), 5.07(\mathrm{t}, J=9.6 \mathrm{~Hz}, 1 \mathrm{H}), 4.71(\mathrm{~d}, J=8.3 \mathrm{~Hz}, 1 \mathrm{H}), 4.2-4.10$ (m, 2H), 3.9-3.8 (m, 2H), 3.7-3.6 (m, 2H), 2.58 (br, 1H, OH), $2.11(\mathrm{~s}, 3 \mathrm{H}), 2.06(\mathrm{~s}, 3 \mathrm{H}), 2.05(\mathrm{~s}, 3 \mathrm{H}), 1.98(\mathrm{~s}, 3 \mathrm{H}) \mathrm{ppm}$.

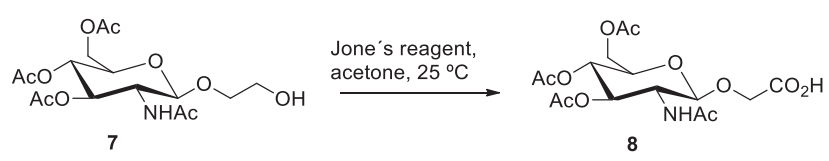

2-Acetamido-3,4,6-tri-O-acetyl-2-deoxy- $\beta$-D-glucopyranosyloxyacetic acid 8 . Jones reagent $(3.5 \mathrm{M}, 0.2 \mathrm{~mL}$, $0.69 \mathrm{mmol}$ ) was added to a stirred solution of 2hydroxyethyl-2-acetamido-3,4,6-tri- $O$-acetyl-2-deoxy- $\beta$-Dglucopyranoside $7(0.15 \mathrm{~g}, 0.35 \mathrm{mmol})$ in acetone $(2 \mathrm{~mL})$ at $0^{\circ} \mathrm{C}$ and the reaction was stirred for $13 \mathrm{~h}$ at $25^{\circ} \mathrm{C}$. Isopropanol was added and the solvent was evaporated. After the addition of $\mathrm{CH}_{2} \mathrm{Cl}_{2}(10 \mathrm{~mL})$ and brine $(10 \mathrm{~mL})$, the layers were separated, the organic layer was washed with brine and dried $\left(\mathrm{Na}_{2} \mathrm{SO}_{4}\right)$, and the solvent was evaporated to afford $0.11 \mathrm{~g}(73 \%)$ of a white solid that was identified as 2 -acetamido-3,4,6-tri- $O$-acetyl-2-deoxy- $\beta$-D-glucopyranosyloxyacetic acid 8 The spectroscopic data of the product were identical to those described in the literature [50]. ${ }^{1} \mathrm{H}-\mathrm{NMR}\left(400 \mathrm{MHz}, \mathrm{CDCl}_{3}\right): \delta 6.57(\mathrm{br} \mathrm{s}, 1 \mathrm{H}), 5.22(\mathrm{t}$, $J=9.6 \mathrm{~Hz}, 1 \mathrm{H}), 5.11(\mathrm{t}, J=9.6 \mathrm{~Hz}, 1 \mathrm{H}), 4.75(\mathrm{~d}, J=8.1 \mathrm{~Hz}$, $1 \mathrm{H}), 4.35$ (app s, 2H), 4.28 (dd, $J=12.1,4.9 \mathrm{~Hz}, 1 \mathrm{H}), 4.15$ (dd, $J=10.7,2.1 \mathrm{~Hz}, 1 \mathrm{H}), 4.1-4.0(\mathrm{~m}, 1 \mathrm{H}), 3.7-3.6(\mathrm{~m}, 1 \mathrm{H})$, 2.11 (s, 3H), 2.06 (s, 3H), 2.03 (s, 3H), 1.97 (s, 3H) ppm.

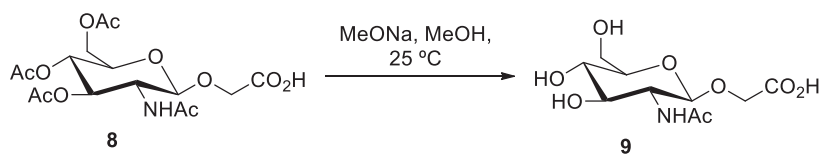

2-Acetamido-2-deoxy- $\beta$-D-glucopyranosyloxyacetic Acid 9. Sodium methoxide $(0.02 \mathrm{~g}, 0.332 \mathrm{mmol})$ was added to a stirred solution of 2-acetamido-3,4,6-tri-O-acetyl-2-deoxy$\beta$-D-glucopyranosyloxyacetic acid $8(0.114 \mathrm{~g}, 0.255 \mathrm{mmol})$ in $\mathrm{MeOH}(6 \mathrm{~mL})$ and the reaction mixture was stirred at $25^{\circ} \mathrm{C}$ for $24 \mathrm{~h}$. After the addition of Dowex-200 the mixture was filtered and the solvent was evaporated. The residue was dissolved in $\mathrm{H}_{2} \mathrm{O}$ and dried under vacuum to afford $0.071 \mathrm{~g}(99 \%)$ of a solid identified as 2-acetamido-2-deoxy$\beta$-D-glucopyranosyloxyacetic acid 9. The spectroscopic data of the product were identical to those described in the literature [50]. ${ }^{1} \mathrm{H}-\mathrm{NMR}\left(400 \mathrm{MHz}, \mathrm{D}_{2} \mathrm{O}\right): \delta 4.49(\mathrm{~d}$, $J=8.4 \mathrm{~Hz}, 1 \mathrm{H}), 4.18(\mathrm{~s}, 2 \mathrm{H}), 3.83(\mathrm{~d}, J=12.2 \mathrm{~Hz}, 1 \mathrm{H})$, 3.70-3.60 (m, 2H), 3.50-3.40 (m, $1 \mathrm{H}), 3.40-3.30(\mathrm{~m}, 2 \mathrm{H})$, 1.97 (s, 3H) ppm. 


\section{Particle functionalization}

A suspension of aminopropylsilane (APS)-coated silicon particles was produced by treatment of $0.1 \mathrm{~g}$ silica particles with APS $(20 \mu \mathrm{L})$ in 2-propanol $(5 \mathrm{~mL})$ at $80^{\circ} \mathrm{C}$ for $2 \mathrm{~h}$. The particles were centrifuged at $3800 \mathrm{rpm}$ for 30 min to remove the excess APS, followed by replacement of the supernatant solution by isopropanol. The particles were re-dispersed by shaking (ultrasound) for $10 \mathrm{~min}$. This protocol was repeated two more times [51].

The particles were centrifuged at $3800 \mathrm{rpm}$ for $30 \mathrm{~min}$ and the supernatant was replaced by dimethylformamine (DMF). Then, a solution of 2-acetamido-2-deoxy- $\beta$-D-glucopyranosyloxyacetic acid 9 (14 mg), benzotriazol-1-yloxy) tris(dimethylamino)phosphonium hexafluorophosphate (BOP, $29 \mathrm{mg}$ ), hydroxybenzotriazole (HOBt, $7 \mathrm{mg}$ ) in DMF (3 mL) and diisopropylethylamine $(30 \mu \mathrm{L})$ were added and the suspension was stirred for $12 \mathrm{~h}$ at $25^{\circ} \mathrm{C}$. The particles were centrifuged at $3800 \mathrm{rpm}$ for $30 \mathrm{~min}$, washed with DMF and the supernatant then replaced by $\mathrm{H}_{2} \mathrm{O}$. The particles were redispersed by shaking (ultrasound) for $10 \mathrm{~min}$. The supernatant was replaced by phosphate buffered saline (PBS, 1x).

To a suspension of the particles in PBS $(2 \mathrm{~mL}) 250 \mu \mathrm{L}$ of a solution of anti-erbB-2/HER-2 $(1 \mu \mathrm{L} / \mathrm{L}$ in PBS) was added and the mixture was shaken at $0^{\circ} \mathrm{C}$ for $12 \mathrm{~h}$. The particles were centrifuged at $3800 \mathrm{rpm}$ for $10 \mathrm{~min}$, and the supernatant was replaced with PBS. The particles were redispersed by shaking (ultrasound) for $3 \mathrm{~min}$ at $0^{\circ} \mathrm{C}$.

\section{Cell culture and viability assay}

Materials: Dulbecco's modified eagle's medium (DMEM, \#302002) and McCoy's 5a medium (\#30-2007) were purchased from ATCC. Fetal bovine serum (FBS, \#S0615) was obtained from Biochrom AG and penicillin/streptomycin (\#15140-122) from Gibco (\#15140-122). L-glutamine (\#25030-024) was purchased from Life Technologies. The viability assay based on Resazurin (\#TOX8) and the 96-well plates (\#CLS3603) in which the viability assay was carried out were obtained from Sigma-Aldrich (St Louis, MO, USA).

MDA-MB-435 human epithelial cells (ATCC \#HTB-129) were seeded and grown in growth medium (DMEM with $4.5 \mathrm{~g} / \mathrm{L}$ glucose supplemented with $10 \% \mathrm{FBS}, 1 \% \mathrm{~L}$-glutamine $(200 \mathrm{mM})$ and $1 \%$ penicillin/streptomycin. SK-BR-3 human breast adenocarcinoma cells (ATCC \#HTB-30) were seeded and grown in another growth medium (McCoy's medium supplemented with $10 \% \mathrm{FBS}, 1 \%$ L-glutamine $(200 \mathrm{mM})$ and $1 \%$ penicillin/streptomycin.

Imaging of the particle internalization: SK-BR-3 cells were seeded on an Ibidi 8-well plate (2E4 cells/well) and left to adhere and grow for 4 days. Subsequently, the cells were incubated with $30 \mu \mathrm{g} / \mathrm{mL}$ PSiP-HER-2 particles for $24 \mathrm{~h}$. The cells were then washed intensively and the cell membrane stained with $20 \mu \mathrm{g} / \mathrm{mL}$ cell mask deep red for $10 \mathrm{~min}$ at $37^{\circ} \mathrm{C}$ before imaging. Images of living cells using transmitted and reflected light were taken with a confocal laser scanning microscope (NIKON TE2000-E). A 650 LP filter was used to collect the fluorescence signal of the cell membrane after excitation at $633 \mathrm{~nm}$, whereas a $515 / 30$ BP filter was used to collect the light reflected by the DyLight 488 labeled PSiP-HER-2 after irradiation with a $488 \mathrm{~nm}$ laser line. As previously reported, the particles exhibit intrinsic photoluminescence because of the presence of the microcavities $[35,36]$.

Viability assay: 20,000 cells (MDA-MB-435 or SK-BR-3) were seeded per well in a 96-well plate and incubated in $100 \mu \mathrm{L}$ of the corresponding cell medium for $48 \mathrm{~h}$ at $37^{\circ} \mathrm{C}$ and $5 \% \mathrm{CO}_{2}$. After this time, different concentrations of particles (PSiNPs or PSiNPs-HER-2) were added and cells were incubated for another $48 \mathrm{~h}$. The viability assay was repeated three times at each concentration. Control viability assays were performed using cells without particles and particles without cells. After incubation, cellular viability was probed. Cells were washed with PBS and a solution of $10 \%$ of resazurin in growth medium was added to each well. Cells were placed in the incubator for $3 \mathrm{~h}\left(37^{\circ} \mathrm{C}\right.$ and $5 \% \mathrm{CO}_{2}$ ). Resazurin is a nonfluorescent molecule that is reduced from the oxidized to the reduced form, resofurin, by metabolically active cells. Resofurin is fluorescent, has a maximum emission wavelength at $585 \mathrm{~nm}$ (red emission), and can be excited from 530 to $560 \mathrm{~nm}$. The fluorescent emission intensity originating from resofurin is proportional to the number of metabolically active (=living) cells. Fluorescence emission was measured with a Fluorolog-3 spectrofluorometer equipped with a microwell plate reader (MicroMax 384) from Horiba JOBIN YVON. The samples were excited at $560 \mathrm{~nm}$ and the emission spectra were collected from 572 to $650 \mathrm{~nm}$. Background was subtracted from the spectra. As the position of the maximum emission, wavelength can be slightly shifted, so the peak emission was averaged from 584 to $586 \mathrm{~nm}$. The emission peak intensity values were normalized, considering a cell viability of $100 \%$ for the control experiments, in which no particles had been added to the cells. The normalized fluorescence emission peak intensities were plotted against the logarithm of the particle concentration, $c f$. Figure 4. Dose-response curves were obtained for SK-BR-3 and MDA-MB-435 exposed to different concentrations of Si-NPs and SiNPsHER2, $c$. Figure 4. The results were fitted to sigmoidal curves and the inflexion point was calculated. The inflexion point represents the $\mathrm{LD}_{50}$ value, which in this case is the concentration of particles at which cell viability is reduced to $50 \%$, i.e. $50 \%$ of the cells are no longer metabolically active. The calculated $\mathrm{LD}_{50}$ values are shown in Table 1 .

\section{Competing interests}

The authors declare that they have no competing interests.

\section{Authors' contributions}

RAA-P, FM, CV, EG-R conceived the idea. RF, IR and FM synthetized the silicon particles; SA, RA, ARdL synthetized the sugar and coupled the antibody to the particles; SC-R, XY, MG-A, PRG and WJP carried out the viability assays. All 
the authors participated in scientific discussions and wrote the paper. All authors read and approved the final manuscript.

\section{Acknowledgements}

The authors acknowledge financial support from the following projects FIS2009-07812, MAT2012-35040, PROMETEO/2010/043, CTQ2011-23167، CrossSERS, FP7 MC-IEF 329131, and HSFP (project RGP0052/2012) and Medcom Tech SA. Xiang Yu acknowledges support by the Chinese government (CSC, Nr. 2010691036)

\section{Author details}

${ }^{1}$ Centro de Tecnologías Físicas, Unidad Asociada ICMM/CSIC-UPV, Universidad Politécnica de Valencia, Av. Los Naranjos s/n, Valencia, 46022 Spain and Instituto de Ciencia de Materiales de Madrid, CSIC, Madrid 28049, Spain. ${ }^{2}$ Servicio de Oncología, Hospital Universitario Madrid-Torrelodones, Madrid 28250, Spain. ${ }^{3}$ Departamento de Química Orgánica, Universidade de Vigo, Vigo 36310, Spain. ${ }^{4}$ Fachbereich Physik, Philipps Universität Marburg, Marburg 35037, Germany. ${ }^{5}$ Medcomtech SA, C/ Catalunya, 83-85 Viladecans, Barcelona 08840, Spain. 'Departamento de Química Física e Inorgánica, Universitat Rovira i Virgili and Centro de Tecnología Química de Catalunya, Carrer de Marcel•lí Domingo s/n, 43007 Tarragona, Spain. ${ }^{7}$ ICREA, Passeig Lluís Companys 23, 08010 Barcelona, Spain.

Received: 24 July 2014 Accepted: 3 September 2014

Published online: 16 September 2014

\section{References}

1. Prasad PN: Introduction to Nanomedicine and Nanobioengineering. New York: Wiley; 2012.

2. Randall CL, Leong TG, Bassik N, Gracias DH: 3D lithographically fabricated nanoliter containers for drug delivery. Adv Drug Del Rev 2007, 59:1547-1561.

3. Reibetanz U, Chen MHA, Mutukumaraswamy S, Liaw ZY, Oh BHL, Venkatraman S, Donath E, Neu BR: Colloidal DNA carriers for direct localization in cell compartments by pH sensoring. Biogeosciences 2010, 11:1779-1784

4. Tasciotti E, Liu X, Bhavane R, Plant K, Leonard AD, Price BK, Cheng MM-C, Decuzzi P, Tour JM, Robertson F, Ferrari M: Mesoporous silicon particles as a multistage delivery system for imaging and therapeutic applications. Nat Nano 2008, 3:151-157.

5. Park J-H, Gu L, von Maltzahn G, Ruoslahti E, Bhatia SN, Sailor MJ: Biodegradable luminescent porous silicon nanoparticles for in vivo applications. Nat Mater 2009, 8:331-336.

6. Hong C, Lee J, Son M, Hong SS, Lee C: In-vivo cancer cell destruction using porous silicon nanoparticles. Anti-Cancer Drugs 2011, 22:971-977. 910.1097/CAD.1090b1013e32834b32859c.

7. Canham LT: Device Comprising Resorbable Silicon for Boron Capture Neutron Therapy. UK Patent Nr. 0302283.7. In Book Device Comprising Resorbable Silicon for Boron Capture Neutron Therapy. UK Patent Nr. 0302283.7 (Editor ed.^eds.). Edited by City: UK Patent Nr. 0302283.7; 2003.

8. Xiao L, Gu L, Howell SB, Sailor MJ: Porous silicon nanoparticle photosensitizers for singlet oxygen and their phototoxicity against cancer cells. ACS Nano 2011, 5:3651-3659.

9. Gil PR, Parak WJ: Composite nanoparticles take Aim at cancer. ACS Nano 2008, 2:2200-2205.

10. Gomella LG: Is interstitial hyperthermia a safe and efficacious adjunct to radiotherapy for localized prostate cancer? Nat Clin Pract Urol 2004, 1:72-73.

11. Maier-Hauff $K$, Ulrich $F$, Nestler $D$, Niehoff $H$, Wust $P$, Thiesen B, Orawa $H_{\text {, }}$ Budach V, Jordan A: Efficacy and safety of intratumoral thermotherapy using magnetic iron-oxide nanoparticles combined with external beam radiotherapy on patients with recurrent glioblastoma multiforme. J Neuro-Oncol 2011, 103:317-324

12. Lal S, Clare SE, Halas NJ: Nanoshell-enabled photothermal cancer therapy: Impending clinical impact. Acc Chem Res 2008, 41:1842-1851.

13. Lee C, Kim H, Hong C, Kim M, Hong SS, Lee DH, Lee WI: Porous silicon as an agent for cancer thermotherapy based on near-infrared light irradiation. J Mater Chem 2008, 18:4790-4795.

14. Osminkina LA, Gongalsky MB, Motuzuk AV, Timoshenko VY, Kudryavtsev AA: Silicon nanocrystals as photo- and sono-sensitizers for biomedical applications. Appl Phys B 2011, 105:665-668.
15. Jain PK, Huang X, El-Sayed IH, El-Sayed MA: Noble metals on the nanoscale: optical and photothermal properties and some applications in imaging, sensing, biology, and medicine. Acc Chem Res 2008, 41:1578-1586.

16. Serda RE, Godin B, Blanco E, Chiappini C, Ferrari M: Multi-stage delivery nano-particle systems for therapeutic applications. Biochim Biophys Acta 1810, 2011:317-329.

17. Xu R, Huang Y, Mai J, Zhang G, Guo X, Xia X, Koay EJ, Qin G, Erm DR, Li Q, Liu X Ferrari M, Shen $\mathrm{H}$ : Multistage vectored siRNA targeting ataxia-telangiectasia mutated for breast cancer therapy. Small 2013, 9:1799-1808.

18. Park JS, Kinsella JM, Jandial DD, Howell SB, Sailor MJ: Cisplatin-loaded porous Si microparticles capped by electroless deposition of platinum. Small 2011, 7:2061-2069.

19. Xue M, Zhong X, Shaposhnik Z, Qu Y, Tamanoi F, Duan X, Zink J: $\mathrm{pH}$-operated mechanized porous silicon nanoparticles. J Am Chem Soc 2011, 133:8798-8801.

20. Canham LT: Bioactive silicon structure fabrication through nanoetching techniques. Adv Mater 1995, 7:1033-1037.

21. Popplewell JF, King SJ, Day JP, Ackrill P, Fifield LK, Cresswell RG, Di Tada ML, Liu K: Kinetics of uptake and elimination of silicic acid by a human subject: a novel application of 32Si and accelerator mass spectrometry. J Inorganic Biochem 1998, 69:177-180.

22. Shabir Q, Pokale A, Loni A, Johnson DR, Canham LT, Fenollosa R, Tymczenko M, Rodríguez I, Meseguer F, Cros A, Cantarero A: Medically biodegradable hydrogenated amorphous silicon microspheres. Silicon 2011, 3:173-176.

23. Chen $Y$, Wan $Y$, Wang $Y$, Zhang $H$, Jiao Z: Anticancer efficacy enhancement and attenuation of side effects of doxorubicin with titanium dioxide nanoparticles. Int J Nanomed 2011, 6:2321-2326.

24. Mackowiak SA, Schmidt A, Weiss V, Argyo C, von Schirnding C, Bein T, Bräuchle C: Targeted drug delivery in cancer cells with Red-light photoactivated mesoporous silica nanoparticles. Nano Lett 2013, 13:2576-2583

25. Li Z, Barnes JC, Bosoy A, Stoddart JF, Zink Jl: Mesoporous silica nanoparticles in biomedical applications. Chem Soc Rev 2012, 41:2590-2605.

26. O'Mara WC, Herring B, Hunt P: Handbook of Semiconductor Silicon Technology. New Jersey: Noyes Publication; 1990

27. Mikulec FV, Kirtland JD, Sailor MJ: Explosive nanocrystalline porous silicon and its Use in atomic emission spectroscopy. Adv Mater 2002, 14:38-41.

28. Clement D, Diener J, Gross E, Kunzner N, Timoshenko WY, Kovalev D: Highly explosive nanosilicon-based composite materials. Phys Stat Sol A 2005, 202:1357-1359.

29. Canham LT: Silicon quantum wire array fabrication by electrochemical and chemical dissolution of wafers. Appl Phys Lett 1990, 57:1046-1049.

30. Canham LT: Properties of Porous Silicon. United Kindom: INSPEC; 1997.

31. Heinrich JL, Curtis CL, Credo GM, Sailor MJ, Kavanagh KL: Luminescent colloidal silicon suspensions from porous silicon. Science 1992, 255:66-68.

32. Littau KA, Szajowski PJ, Muller AJ, Kortan AR, Brus LE: A luminescent silicon nanocrystal colloid via a high-temperature aerosol reaction. J Phys Chem 1993, 97:1224-1230.

33. Menz WJ, Shekar S, Brownbridge GPE, Mosbach S, Körmer R, Peukert W, Kraft M: Synthesis of silicon nanoparticles with a narrow size distribution: a theoretical study. J Aerosol Sci 2012, 44:46-61.

34. Swihart MT, Girshick SL: Thermochemistry and kinetics of silicon hydride cluster formation during thermal decomposition of silane. J Phys Chem B 1998, 103:64-76.

35. Fenollosa R, Ramiro-Manzano F, Tymczenko M, Meseguer F: Porous silicon microspheres: synthesis, characterization and application to photonic microcavities. J Mater Chem 2010, 20:5210-5214.

36. Ramiro-Manzano F, Fenollosa R, Xifré-Pérez E, Garín M, Meseguer F: Porous silicon microcavities based photonic barcodes. Adv Mater 2011 23:3022-3025

37. Kastl L, Sasse D, Wulf V, Hartmann R, Mircheski J, Ranke C, Carregal-Romero S, Martínez-López JA, Fernández-Chacón R, Parak WJ, Elsasser HP, Rivera-Gil P: Multiple internalization pathways of polyelectrolyte multilayer capsules into mammalian cells. ACS Nano 2013, 7:6605-6618.

38. Schweiger C, Hartmann R, Zhang F, Parak W, Kissel T, Rivera_Gil P: Quantification of the internalization patterns of superparamagnetic iron oxide nanoparticles with opposite charge. J Nanobiotech 2012, 10:28.

39. Sanles-Sobrido M, Exner W, Rodríguez-Lorenzo L, Rodríguez-González B, Correa-Duarte MA, Álvarez-Puebla RA, Liz-Marzán LM: Design of SERS-encoded, submicron, hollow particles through confined growth of encapsulated metal nanoparticles. J Am Chem Soc 2009, 131:2699-2705. 
40. Slamon D, Eiermann W, Robert N, Pienkowski T, Martin M, Press M, Mackey J, Glaspy J, Chan A, Pawlicki M, Pinter T, Valero V, Liu MC, Sauter G, von Minckwitz G, Visco F, Bee V, Buyse M, Bendahmane B, Tabah-Fisch I, Lindsay MA, Riva A, Crown J: Adjuvant trastuzumab in HER2-positive breast cancer. N Eng/ J Med 2011, 365:1273-1283.

41. Agus DB, Gordon MS, Taylor C, Natale RB, Karlan B, Mendelson DS, Press MF, Allison DE, Sliwkowski MX, Lieberman G, Kelsey SM, Fyfe G: Phase I clinical study of pertuzumab, a novel HER dimerization inhibitor, in patients with advanced cancer. J Clin Oncol 2005, 23:2534-2543.

42. Colombo M, Mazzucchelli S, Montenegro JM, Galbiati E, Corsi F, Parak WJ, Prosperi D: Protein oriented ligation on nanoparticles exploiting O6-alkylguanine-DNA transferase (SNAP) genetically encoded fusion. Small 2012, 8:1492-1497.

43. Franklin MC, Carey KD, Vajdos FF, Leahy DJ, de Vos AM, Sliwkowski MX: Insights into ErbB signaling from the structure of the ErbB2-pertuzumab complex. Cancer Cell 2004, 5:317-328.

44. Paris L, Cecchetti S, Spadaro F, Abalsamo L, Lugini L, Pisanu ME, Lorio E, Natali PG, Ramoni C, Podo F: Inhibition of phosphatidylcholine-specific phospholipase $\mathrm{C}$ downregulates HER2 overexpression on plasma membrane of breast cancer cells. Breast Cancer Res 2010, 12:R27.

45. Fenollosa R, Meseguer F, Tymczenko M: Silicon colloids: from microcavities to photonic sponges. Adv Mater 2008, 20:95-98.

46. Jasinski JM, Gates SM: Silicon chemical vapor deposition one step at a time: fundamental studies of silicon hydride chemistry. Acc Chem Res 1991, 24:9-15

47. Xiao Q, Liu Y, Qiu Y, Zhou G, Mao C, Li Z, Yao Z-J, Jiang S: Potent antitumor mimetics of annonaceous acetogenins embedded with an aromatic moiety in the left hydrocarbon chain part. J Med Chem 2010, 54:525-533.

48. Allman SA, Jensen HH, Vijayakrishnan B, Garnett JA, Leon E, Liu Y, Anthony DC, Sibson NR, Feizi T, Matthews S, Davis BG: Potent fluoro-oligosaccharide probes of adhesion in toxoplasmosis. ChemBioChem 2009, 10:2522-2529.

49. Chambers DJ, Evans GR, Fairbanks AJ: Elimination reactions of glycosyl selenoxides. Tetrahedron 2004, 60:8411-8419.

50. Tomabechi Y, Suzuki R, Haneda K, Inazu T: Chemo-enzymatic synthesis of glycosylated insulin using a GlcNAc tag. Bioorg Med Chem 2010, 18:1259-1264.

51. Pastoriza-Santos I, Gomez D, Perez-Juste J, Liz-Marzan LM, Mulvaney P. Optical properties of metal nanoparticle coated silica spheres: a simple effective medium approach. Phys Chem Chem Phys 2004, 6:5056-5060.

doi:10.1186/s12951-014-0035-7

Cite this article as: Fenollosa et al:: Silicon particles as trojan horses for potential cancer therapy. Journal of Nanobiotechnology 2014 12:35.

\section{Submit your next manuscript to BioMed Central and take full advantage of:}

- Convenient online submission

- Thorough peer review

- No space constraints or color figure charges

- Immediate publication on acceptance

- Inclusion in PubMed, CAS, Scopus and Google Scholar

- Research which is freely available for redistribution 